\title{
Research on Quality of Transaction Standards: The Maturity of a Research Topic*
}

\author{
Erwin Folmer ${ }^{1,2,3}$, Wouter Berends ${ }^{1}$, Paul Oude Luttighuis ${ }^{4}$, \\ Jos van Hillegersberg ${ }^{1}$, and Rutger Lammers ${ }^{1,3}$ \\ ${ }^{1}$ University of Twente \\ ${ }^{2}$ TNO Information and Communication Technology \\ ${ }^{3}$ Netherlands Open in Connection \\ ${ }^{4}$ Novay \\ erwin.folmer@tno.nl
}

\begin{abstract}
This paper contains the results of a systematic literature review executed to determine the coverage of transaction standards in top information systems (IS) and management journals. Specifically, it aims to identify a research gap with respect to this topic. The top 25 journals are thoroughly searched and the selected publications are classified in order to make grounded statements. A moderate amount of literature found specifically aims at transaction standards. Hardly any research is found on quality aspects of transaction standards, which therefore counts as the research gap.
\end{abstract}

Keywords: quality, transaction, standard, adoption, interoperability, literature, review.

\section{Introduction}

Information systems without standards are hard to imagine. Also in the e-business domain, standards are gaining importance and attention. Much focus is nowadays on the concept of inter-organizational interoperability: the ability of two or more sociotechnical systems to exchange information, to interpret the information that has been exchanged and to act upon it in an appropriate and agreed-upon matter [16]. Interorganizational interoperability is of special interest in the e-business domain. Standardization is one of the means to achieve such interoperability. In literature, different terms are used for this kind of standards, such as e-business standards, vertical and (business) transaction standards. A standard, in the simplest sense, is an agreed-upon way of doing something [20]. Transaction standards are often developed inside a specific industry domain, often outside the traditional standard setting organizations (also called standard development organization).

This paper is a continuation of the study Top IS Research on Quality of Transaction Standards: A structured literature review to identify a research gap which has been presented at the 6th International Conference on STANDARDIZATION and INNOVATION in INFORMATION TECHNOLOGY (SIIT 2009), September 9th 2009, Tokyo Japan. 
As standards are means to an end: interoperability. A general assumption is that a good standard will improve interoperability. Surprisingly, the question as to what makes a good standard is relatively rarely given explicit treatment in the literature on standardization [4][5], although Markus et al. [15] note that the technical contents of the standards will have impact on the standards diffusion. This suggests a relevant quality aspect attached to the technical content.

\subsection{Goal}

This research is a first step in developing knowledge on quality of transaction standards. The ultimate goal is to enable the measurement of quality of transaction standards. The goal of this paper is limited to assessing the topic of quality of transaction standards as a possible research gap. A derived goal, and contribution to the knowledge area, is the analysis of coverage of this research subject within the most important Information Systems and Management literature.

\subsection{Research Questions}

In order to get an overview of existing state-of-the-art in top journals regarding the topic of quality of transaction standards, the following research questions have been constructed:

1. Are there any studies related to quality of transaction standards published?

2. Are there many studies related to transaction standards, and specific for certain domains (verticals)?

Based on the outcome of the structured literature review it will be interesting to see what other remarkable insights can be learned. These will be presented in the discussion section. as well as a preliminary view of main contributions of all selected studies based on a selection of only several papers. The corresponding research question is:

3. What can be learned from selecting a minimal set of studies identified within the structured literature review, as preliminary results of assessing all studies?

\subsection{Research Method}

A systematic literature review [15] has been set-up and performed to enable grounded statements to the research questions and to assure that no major publication will be missed. The search was constructed based on Rumsey's [17] description of planning the campaign. The goal of identifying a research gap implies that the top 25 information systems journals and top 25 management journals should be included (and restricted to) in the search phase. Search engines were selected based on our analysis of coverage of the journals in the search engines. The selection of journals and search engines was based on previous work [16][12][18]. More information on the research method, journals and search engines is available in the corresponding paper [8].

From the domain of quality measurement of business transaction standards, keywords have been selected. To assure the quality of the keywords, the selection was done iteratively by testing the keywords in the search engine and by adding multiple synonyms. The selected keywords are visualized in figure 1. 




Fig. 1. Keywords

The searches conducted with the search engines yielded several articles per query. Search queries where designed so that manageable amounts of publications were found. Then, an exclusion process has been initiated as described by [22]. First, abstracts and keywords were assessed manually on relevance; in order to ensure that nothing was overlooked this process was done twice and by two individuals. This resulted in a list of 100 papers. A second screening on relevance took place by scanning the whole publication, again double-blinded. This resulted in a list of 48 publications, these publications were classified according to the framework. During this classification we found out that an additional 5 papers were out of scope, which resulted in a final list of 43 publications (the complete list can be found in the appendix). Even though this selection process has been carried out, it is a weak spot in this methodology, because the selection criteria are subjective and difficult to trace. In the first step many papers related to software engineering, healthcare, multimedia and accountancy were removed. The second step removed publications with only marginal attention for standards.

\section{Classification Framework and Results}

Based on the research questions and other systematic literature review research [23] several classifiers regarding the standardization subject were selected, as well as classifiers regarding the research rigor. They are:

- Topic: The topic (domain) of the research

- Standard Lifecycle: The phase within the lifecycle of a standard

- Standards View: The actor's viewpoint on the subject

- Type of Standard: What kind of standards is the paper about?

- Research Approach: The research approach (fundament) for the paper

- Research Method: The applied research method of the paper 
Like the selection process, the classification process has been carried out double blinded to improve the quality of the results. Differences in the classification have been solved by analyzing the differences and achieving consensus from both individuals and to make use of a third individual. The complete list of papers and their classification can be found in [8].

\subsection{Topic}

Based on the keywords and brainstorming, five different topics have been identified.

Table 1. Standardisation topics

\begin{tabular}{|l|l|l|}
\hline Topic & Description & Count \\
\hline $\begin{array}{l}\text { Standards } \\
\text { Lifecycle }\end{array}$ & $\begin{array}{l}\text { The publication discusses one or more steps from the } \\
\text { standards life cycle, such as standards development or } \\
\text { standards diffusion. }\end{array}$ & 16 \\
\hline $\begin{array}{l}\text { Standards and } \\
\text { Interoperability }\end{array}$ & $\begin{array}{l}\text { The publication concerns interoperability issues, or other } \\
\text { higher-level aspects of standardization. }\end{array}$ & 3 \\
\hline $\begin{array}{l}\text { Standards } \\
\text { Quality }\end{array}$ & $\begin{array}{l}\text { The publication addresses the quality aspects of f } \\
\text { standards. }\end{array}$ & 1 \\
\hline $\begin{array}{l}\text { Standards } \\
\text { Policy/Strategy/I } \\
\text { mpact (PSI) }\end{array}$ & $\begin{array}{l}\text { The publication concerns economics of standardization, } \\
\text { business cases, general advantages, the impact of usage } \\
\text { ofthe standard, or the effectiveness of standards. }\end{array}$ & 11 \\
\hline $\begin{array}{l}\text { Standards } \\
\text { Organization }\end{array}$ & $\begin{array}{l}\text { The publication concerns standards setting organizations } \\
\text { (SSO) and standards development organizations (SDO), } \\
\text { National Standards Organizations, etc. }\end{array}$ & 2 \\
\hline
\end{tabular}

Remarkable is the low number of studies in the third and fifth categories. The second category contains papers that are more high level and standards are often not the main subject. This is also the reason why especially these papers could not be scored on the Standards Lifecycle (see next table).

\subsection{Standards Lifecycle}

Considerable literature on standards lifecycles exists. Amongst others are Cargill [3], De Vries [5] and Egyedi and Blind [7]. Söderström [19] compared seven different standards life cycle models, and build a new model based on that. Each of these seven may be useful for classification, but we chose Söderström's extended general lifecycle as a start, because it takes most other lifecycle models into account.

Although this model fits our purposes we need to condense it for pragmatic reasons; it contains too many steps, which may result in fragmented results. We combined the Initiate and Standards Development phase (and kept the latter name), and did the same for Develop Product, Conformity Assessment, Educate and Implement. Also, Feedback is combined with Maintain. In comparison with lifecycle models from other domains (e.g. software domain [1]) the standardization lifecycle models found are 


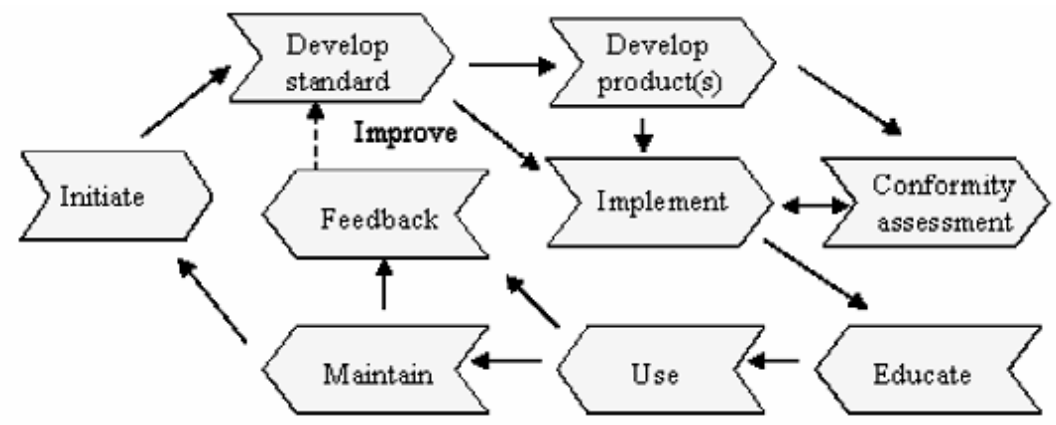

Fig. 2. Extended general lifecycle [19]

Table 2. Standards Lifecycle

\begin{tabular}{|l|l|l|}
\hline $\begin{array}{l}\text { Standards } \\
\text { Lifecycle }\end{array}$ & Description & Count \\
\hline Development & The creation and development phase of a standard. & 4 \\
\hline Implement & $\begin{array}{l}\text { Implementation of the standard in products or systems, } \\
\text { including implementation services. }\end{array}$ & 1 \\
\hline Use & $\begin{array}{l}\text { The usage of the standard, the adoption in the market } \\
\text { (diffusion). }\end{array}$ & 23 \\
\hline Maintain & $\begin{array}{l}\text { The maintenance phase where standards (periodically) } \\
\text { are improved to current needs. }\end{array}$ & - \\
\hline Retirement & $\begin{array}{l}\text { The phase when a standard is withdrawn from } \\
\text { maintenance. }\end{array}$ & - \\
\hline Not applicable & \multicolumn{1}{|l}{} \\
\hline
\end{tabular}

open-ended: they lack an "end" phase. Based on the Enterprise Unified Process, we therefore decided to add a Retirement phase to the lifecycle model.

Remarkable are the low scores for the maintain and retirement phases, and the high score for the use/adoption phase. The table below contains the results on the Standards View.

\subsection{Standards View}

Different roles take part in the stages identified in the lifecycle model. We however see no one-to-one correspondence between lifecycle stages and roles. For instance, it is possible to have a user view on the implementation of standards, but also the view of the creator of the standard on implementation phase. Krechmer [10] identifies three main recognizable views on standards: User, Implementer and Creator. We added the Policy Maker role. One might argue that this constitutes a specific type of user, but for our goals we decided to add this additional view. 
Table 3. Standards Viewpoints

\begin{tabular}{|l|l|l|}
\hline $\begin{array}{l}\text { Standards } \\
\text { view }\end{array}$ & Description & Count \\
\hline Creator & The developer of the standard. (creates the standard) & 7 \\
\hline Implementer & $\begin{array}{l}\text { The implementer of the standard. (implements the } \\
\text { created standard) }\end{array}$ & 15 \\
\hline User & $\begin{array}{l}\text { The (end) user of the standard. (uses the implementation } \\
\text { of the standard) }\end{array}$ & 20 \\
\hline Policy Maker & $\begin{array}{l}\text { The policy maker about standards. (develops policy } \\
\text { about the standard) }\end{array}$ & 1 \\
\hline
\end{tabular}

This shows, in combination with the results on standards lifecycle, that most of the papers are dealing with a user view on standards. Hardly any have a creator's view, or deal with the development life cycle phase of the standard. The table below contains the results on the Type of Standards.

\subsection{Type of Standards}

Many classification of standards exists [4]. As this paper focuses on transaction standards we chose to use the classification also used by Steinfield et al. [21], as closest fit to our research questions.

Table 4. Type of standards

\begin{tabular}{|l|l|l|}
\hline $\begin{array}{l}\text { Type of } \\
\text { Standard }\end{array}$ & Definition & Count \\
\hline Syntactical & $\begin{array}{l}\text { The scope is related to technical standards like TCP, IP, } \\
\text { SOAP }\end{array}$ & 10 \\
\hline $\begin{array}{l}\text { Semantic }- \\
\text { Horizontal }\end{array}$ & $\begin{array}{l}\text { The scope is related to cross industry standards like } \\
\text { ebXML, UBL }\end{array}$ & 11 \\
\hline $\begin{array}{l}\text { Semantic }- \\
\text { Vertical }\end{array}$ & $\begin{array}{l}\text { The scope is related to industry standards like MISMO, } \\
\text { hr-XML }\end{array}$ & 14 \\
\hline All & Multiple types are covered & 8 \\
\hline
\end{tabular}

The classification process for this category was somewhat difficult, because many papers did not completely focus on one type. Also, the emphasis was not always clear. It is remarkable that only 14 papers have been found that mainly deal with vertical standards, as the keywords were specifically aimed to find as many as possible. Next are the results on the Research Approach and Research Method.

\subsection{Research Approach}

An often-used classification of the research approach is from Orlikowski and Baroudi [14]: 
Table 5. Research approaches

\begin{tabular}{|l|l|l|}
\hline $\begin{array}{l}\text { Research } \\
\text { Approach }\end{array}$ & Description & Count \\
\hline $\begin{array}{l}\text { Positivist } \\
\text { (Theoretically } \\
\text { grounded) }\end{array}$ & $\begin{array}{l}\text { Propositions or hypothesis are formulated and tested, or } \\
\text { analytical propositions are derived. Typically quantifiable } \\
\text { measures on stated populations (Klein \& Myers, 1999). }\end{array}$ & 5 \\
\hline $\begin{array}{l}\text { Positivist } \\
\text { (Descriptive) }\end{array}$ & $\begin{array}{l}\text { Describes current practices, without theoretical grounding } \\
\text { or rigorous data collection and analysis. They describe } \\
\text { issues to be shared with the community. Typically case } \\
\text { studies (Orlikowski \& Baroudi, 1991). }\end{array}$ & 26 \\
\hline Critical & $\begin{array}{l}\text { Critical perspective if the main task is being seen as being } \\
\text { one of social critique, whereby the restrictive and } \\
\text { alienating conditions of the status quo are brought to light } \\
\text { (Klein \& Myers, 1999). }\end{array}$ & 6 \\
\hline Interpretive & $\begin{array}{l}\text { A basis premise is that the perspective is fundamentally } \\
\text { subjective, and thus, attempts to understand the } \\
\text { phenomena through the meaning that participants assign to } \\
\text { them (Orlikowski \& Baroudi, 1991; Wareham, 2005). } \\
\text { Typically orientated at social constructs, or the context of } \\
\text { information systems. }\end{array}$ & 6 \\
\hline
\end{tabular}

Table 6. Types of Research Methods

\begin{tabular}{|l|l|l|}
\hline $\begin{array}{l}\text { Research } \\
\text { Method }\end{array}$ & Description & Count \\
\hline Conceptual & $\begin{array}{l}\text { Conceptual analysis, theoretical analysis, mathematical } \\
\text { models, analysis or narration based upon author's } \\
\text { experience, observation or thoughts. No strong empirical } \\
\text { evidence to support author's conclusion. Descriptions of } \\
\text { current practices, situations and imagined scenarios. }\end{array}$ & 11 \\
\hline $\begin{array}{l}\text { Data } \\
\text { Analysis/ } \\
\text { Exprey/ }\end{array}$ & $\begin{array}{l}\text { Mail survey, online survey, use of questionnaires to obtain } \\
\text { quantitative or qualitative data. Lab experiment, field } \\
\text { experiment, free simulation. Document analysis, content } \\
\text { analysis, secondary data analysis, field data analysis, and } \\
\text { other analysis based on data not from questionnaire } \\
\text { instruments and/or experimentation. }\end{array}$ & 5 \\
\hline Review & $\begin{array}{l}\text { Literature review, historical rendition, commentaries, } \\
\text { current status review, practice review. }\end{array}$ & 9 \\
\hline Development & $\begin{array}{l}\text { Techniques, methods, frameworks, instruments to develop } \\
\text { some technical application, system, protocol, etc. }\end{array}$ & 7 \\
\hline Case Study & $\begin{array}{l}\text { Intensive analysis of cases based upon interviews, } \\
\text { observations and analysis in some specific context. }\end{array}$ & 11 \\
\hline Other & Ethnography, action research, other. & - \\
\hline
\end{tabular}


Remarkable is the low amount of papers with a positivist approach, fundamentally grounded with thorough data analysis, and the high amount of descriptive research.

\subsection{Research Method}

Wareham [23] uses for his e-commerce literature review: Conceptual, Survey, Experiment, Development, Data Analysis, Case Study, Review, Others. Our literature review parallels Wareham's, although the subject is different. The following table is based on Wareham's [23], but slightly adapted by combining Survey, Experiments and Data Analysis into one category.

\section{Findings}

This section revisits the first two research questions.

1. Are there any papers related to quality of transaction standards?

Within these top journals hardly any (only 1 paper) research has been published about the quality of transaction standards. This clearly suggests that quality of transaction standards constitutes a research gap. With only two results, the subject of standardization organizations can be called a research gap as well.

2. Are there many papers related to transaction standards, specifically for certain domains (verticals)?

Although the keywords were specifically aimed at transaction standards, including search terms such as e-business and vertical, only fourteen papers have been found that deal with vertical industry standards. Much attention is paid to technical standards, but research regarding vertical standards seems not to reach major journals. The fourteen papers found moreover revisit the same vertical standards, which makes the unique number even lower.

\section{Discussion}

The outcome of structured literature review was valuable for answering the research questions, but gave also insight to other relevant issues which will be presented in this discussion section.

Remarkable is that all six MISQ papers were part of a special issue on standard making (Volume 30, August 2006). These papers are probably the most acclaimed studies on standardization. Although the structured literature review was limited to top 25 journals, it is remarkable that when broadening the scope than again one of the most valuable resource is a special section within Electronic Markets (Volume 15, Issue 4). Broadening up the scope from transaction standards to general standardisation, and removing the limitation of top journals, a wide range of studies appear in different gremia. For instance the following groups / journals / conferences communicate about standardisation studies: 
- EURAS: European Academy for Standardisation (conference, proceedings, book series)

- SIIT: International Conference on Standardization and Innovation in Information Technology

- ICES: International Cooperation for Education about Standardization

- ITU-T Kaleidoscope: International Telecommunication Union, Telecommunication Standardization Sector, Kaleidoscope event. JITSR: International Journal of IT Standards and Standardization Research I-ESA : The international conference on Interoperability for Enterprise Software and Applications

- IFIP WG 5.8: International Federation for Information Processing, Workgroup Enterprise Interoperability

Some topics (like Standardization organization) that was not covered in top journals is often covered in those journals and other edited books by members of the EURAS community. Based on these findings we may conclude that:

- Standardisation studies are common, but mainly present in journals outside top 25 journals, or limited to special issues in higher ranked journals.

- Although standardisation studies are common, studies specifically aimed at transaction standards are scarce in general. Although not proven it is expected that the proven research gap for top journals is also valid for all journals.

We have to select a minimal set of studies in order to be able to discuss the final research question:

3. What can be learned from selecting a minimal set of studies identified within the structured literature review, as preliminary results of assessing all studies?

Noticeable is that healthcare and financial domain are often used as context for the studies on business transaction standardization. Looking in general, but for this discussion specifically at both special issues, the amount of case studies is also remarkable. In general not only the amount of cases, but there is also overlap in the cases itself. For instance the MISMO (mortgage) case is twice listed on the list of 43 selected studies. While half of the special issue MISQ papers are case studies, it is even two-third of the studies presented in the special section of electronic markets. It seems that case study as research method is appropriate when transaction standards are involved. Many of the case studies focus on the adoption (diffusion) of the standard. Arguable the most valuable case studies are the MISMO case [11] and RosettaNet [2]. Interesting is to see what we can learn from comparison between different transaction standards (and different standards development organisations). There is only one study [13], to this authors knowledge, in which such a valuable comparison has been performed. Next to these three papers there are several studies that can be seen as fundament for this area of expertise, however many have a different viewpoint, like for instance the economics of standardization. In our research focussed at improving the quality of transaction standards, a good fundament for the development viewpoint is the conceptual framework of Zhao et al. [23], while the conceptual model of Zhu et al. [25] is appropriate for the adoption viewpoint. 
This leads to a list of five valuable contributions related to the domain of transaction standards, and related to the subject of development and adoption of high quality standards resulting in interoperable inter-organizational systems, presented in the table below:

Table 7. List of valuable contributions

\begin{tabular}{|c|c|}
\hline Type & Conceptual -Development \\
\hline Study & $\begin{array}{l}\text { Vertical E-Business Standards and Standards Development } \\
\text { Organizations: A Conceptual Framework [24] }\end{array}$ \\
\hline Contribution & $\begin{array}{l}\text { It proves the uniqueness of e-business standards, in comparison } \\
\text { with other standards (in particular IT product standards). It } \\
\text { describes challenges faced by the vertical e-business SDO's } \\
\text { (different organisation than traditional SDO's like ISO) such as } \\
\text { rapid technology development and divergent preferences of } \\
\text { stakeholders. And most important it presents a Participants - } \\
\text { Technical content - Institutional structure framework for studying } \\
\text { vertical e-business standards. These three components are } \\
\text { interrelated and determine the performance of the SDO, implying } \\
\text { that the SDO should address all three components in an efficient } \\
\text { and balanced way. The three components consists of the following } \\
\text { features: } \\
\text { Participants (number, sector, bargaining power) } \\
\text { Technical contents (maturity) } \\
\text { Institutional structures (structure, procedures, openness) }\end{array}$ \\
\hline Type & Conceptual - Adoption \\
\hline Study & $\begin{array}{l}\text { Migration to Open-Standard Interorganisational Systems: Network } \\
\text { Effects, Switching Costs and Path Dependency [25] }\end{array}$ \\
\hline Contribution & $\begin{array}{l}\text { It focuses on the migration to an Interorganisational system (IOS) } \\
\text { based on open standards, including XML based horizontal and } \\
\text { vertical standards. } \\
\text { It provides a conceptual model, supported by a large scale survey, } \\
\text { for open standard IOS adoption. This conceptual model indicates } \\
\text { three variables influencing adoption of the standard: } \\
\text { 1. Network Effects (Trading community influence, Peer adoption) } \\
\text { 2. Expected Benefits (influenced by Network Effects) } \\
\text { 3. Adoption costs (Financial costs, Managerial complexity, } \\
\text { Transactional risk, Legal barriers) } \\
\text { While adoption costs are a significant barriers there is a dependency } \\
\text { based on the path taken. In this study non-EDI users were } \\
\text { insensitive to adoption costs, in contrary to EDI users. }\end{array}$ \\
\hline
\end{tabular}


Table 7. (continued)

\begin{tabular}{|c|c|}
\hline Type & Case Study - Adoption \\
\hline Study & $\begin{array}{l}\text { Industry-Wide Information Systems Standardardisation as } \\
\text { Collective Action: The Case of the U.S. Residential Mortgage } \\
\text { Industry [11] }\end{array}$ \\
\hline Contribution & $\begin{array}{l}\text { This study look at the development and diffusion (adoption) of the } \\
\text { MISMO standard based on the viewpoint of collective action. } \\
\text { Based on the MISMO case four propositions are formulated for } \\
\text { vertical standards development and adoption in general: } \\
\text { Proposition 1: To successfully develop a vertical standard that meet } \\
\text { the business needs for interoperability it is necessary to ensure } \\
\text { participation of representative members of heterogeneous user } \\
\text { groups, and avoid natural tendency to splinter into rival } \\
\text { homogeneous groups. } \\
\text { Proposition 2: To successfully achieve adoption it must be ensured } \\
\text { that users groups that have the greatest ability to influence adoption } \\
\text { must be present in the development process without having } \\
\text { disproportionate influence on the content of the standard. } \\
\text { Proposition 3: To successfully achieve adoption a set of tactics is } \\
\text { needed that jointly solves the standards development dilemma } \\
\text { without jeopardizing the solution to the adoption dilemma. } \\
\text { This suggest that there is a relation between the development } \\
\text { choices and the adoption of the standard, which is also present in } \\
\text { the final proposition: } \\
\text { Proposition 4: The success of the adoption of the standard is } \\
\text { affected by the technical content of the standard, which is affected } \\
\text { by the tactics used to solve the development dilemma. }\end{array}$ \\
\hline Type & Case Study - Adoption \\
\hline Study & $\begin{array}{l}\text { Standards Development and Diffusion, A Case Study of RosettaNet } \\
\text { [2] }\end{array}$ \\
\hline Contribution & $\begin{array}{l}\text { It focuses on the adoption of RosettaNet standards, and presents } \\
\text { categories of adoption strategies and lessons learned regarding } \\
\text { development and adoption. Adoption (Diffusion) strategies can be } \\
\text { classified in four categories: } \\
\text { 1. Market: Promote awareness } \\
\text { 2. Technology: Improve standard (lowering costs of implementation) } \\
\text { 3. Policy: Change regulatory environment } \\
\text { 4. Relational: Co-opt key players to pressure their trading partners }\end{array}$ \\
\hline
\end{tabular}


Table 7. (continued)

\begin{tabular}{|c|c|}
\hline & $\begin{array}{l}\text { The presented lessons learned from the RosettaNet case are: } \\
\text { - Only organization involvement that are committed to solving the } \\
\text { problem. } \\
\text { - Focused, quick, problem solving approach to standard setting. } \\
\text { - Investing significantly in standards adoption. } \\
\text { - There is no one right approach for to the standards development } \\
\text { process, even not a full open approach. } \\
\text { - Adoption strategy should be aligned with the development } \\
\text { process. } \\
\text { The set of adoption strategies (see above) should be locally adapted. }\end{array}$ \\
\hline Type & Comparison of multiple cases \\
\hline Study & $\begin{array}{l}\text { Interorganisational System Standards Development in Vertical } \\
\text { Industries [13] }\end{array}$ \\
\hline Contribution & $\begin{array}{l}\text { Based on a comparison of nine different vertical standards, key } \\
\text { drivers, differences and similarities are identified. Key drivers for } \\
\text { vertical standards development are: } \\
\text { 1. Technological innovations (Internet, XML, etc) } \\
\text { 2. Need for interoperability (to survive) } \\
\text { 3. Value proposition of vertical standards consortium (pooling of } \\
\text { R\&D, time savings renegotiating with each new trading partner, } \\
\text { etc) } \\
\text { Differences between vertical standards include alignment with more } \\
\text { established organisations, balance between vertical and horizontal } \\
\text { focus, adoption with the target domains including the use of } \\
\text { tracking mechanisms for monitoring adoption. Similarities include } \\
\text { non-profit status, vertical orientation, provision of standards freely, } \\
\text { vendor neutral, platform independent, membership and fee } \\
\text { structures. } \\
\text { Another important contribution is the interorganisational system } \\
\text { (IOS) standards development cycle, containing of the following } \\
\text { phases: } \\
\text { 1. Choreography \& Modularity (key cross-company business } \\
\text { processes) } \\
\text { 2. Prioritize \& Schedule (planning of business processes) }\end{array}$ \\
\hline
\end{tabular}


Table 7. (continued)

\begin{tabular}{|l|l|}
\hline $\begin{array}{l}\text { 3. Document \& Standardize (develop specifications sets, including } \\
\text { technology) }\end{array}$ \\
4. Review \& Test (permit user community to provide feedback) \\
$\begin{array}{l}\text { 5. Implement \& Deploy (provide implementation support and } \\
\text { forecast adoption) } \\
\text { 6. Compliance \& Certification (validate standards conformance to } \\
\text { insure interoperability) }\end{array}$ \\
\hline
\end{tabular}

The selection of most relevant studies for the research domain of transaction standards is suggesting by selecting two studies from outside top 25 journals, that a scope of only top 25 journals is too limited for this area of expertise. A possible indication of immaturity is the inconsistent use of terms for this type of standards within these five studies, including transaction standards, IOS standards, vertical (information systems) standards and semantic standards.

\section{Conclusions}

At least two research gaps have been identified, which was the primary focus of this research. Also the second goal was achieved; the overview gives some remarkable insights of the coverage of standardization research within the top IS and management journals. It is important to notice though that the validity of these conclusions is limited to the set of journals we have investigated.

Based on the five selected studies, we can conclude that there is a need for transaction standards [13][24]. The development strategy of the transaction standard, which should be aligned with the adoption strategy [2][11] will determine the technical content, which will affect adoption [11]. A justification for further research on the quality of standards, including the quality of the technical content.

The goal of this research, as has been set earlier, has been achieved by declaring the quality of transaction standards as research gap. However, this is only a first step in achieving the ultimate goal of measuring the quality of transaction standards. The second step is to deeply analyze the 43 selected studies on its value for this ultimate goal, and to broaden the horizon with searching and analyzing of studies beyond the top journals.

\section{References}

1. Ambler, S.W.: Enterprise Unified Process (EUP) (2009), http: / / www. enterpriseunifiedprocess.com/

2. Boh, W.F., Soh, C., Yeo, S.: Standards development and diffusion: A case study of RosettaNet. Communications of the ACM 50(12), 57-62 (2007) 
3. Cargill, C.F.: A Five-Segment Model for Standardization. In: Kahin, B., Abbate, J. (eds.) Standards Policy for Information Infrastructure, pp. 79-99. The MIT Press, Cambridge (1995)

4. De Vries, H.J.: IT Standards Typology. In: Jakobs, K. (ed.) Advanced Topics in Information Technology Standards and Standardization Research, vol. 1, pp. 1-26. Idea Group Publishing, Hershey (2006)

5. De Vries, H.J.: Fundamentals of Standards and Standardization. In: Hesser, W., Feilzer, A., De Vries, H.J. (eds.) Standardisation in Companies and Markets, 2nd edn., pp. 1-43. Helmut Schmidt University, Hamburg (2007)

6. DuBois, F.L., Reeb, D.: Ranking the international business journals. Journal of International Business Studies 31(4), 689-704 (2000)

7. Egyedi, T.M., Blind, K.: General Introduction. In: Egyedi, T.M., Blind, K. (eds.) The Dynamics of Standards, pp. 1-12. Edward Elgar, Cheltenham (2008)

8. Folmer, E., Berends, W., Oude Luttighuis, P., Van Hillegersberg, J.: Top IS research on quality of transaction standards, a structured literature review to identify a research gap. Paper Presented at the 6th International Conference on Standardization and Innovation in Information Technology, Tokyo, Japan (2009)

9. Klein, H.K., Myers, M.D.: A Set of Principles for Conducting and Evaluating Interpretive Field Studies in Information Systems. MIS Quarterly: Management Information Systems 23(1), 67 (1999)

10. Krechmer, K.: Open Standards Requirements. In: Jakobs, K. (ed.) Advanced Topics in Information Technology Standards and Standardization Research, vol. 1, pp. 27-48. Idea Group Publishing, Hershey (2006)

11. Markus, M.L., Steinfield, C.W., Wigand, R.T., Minton, G.: Industry-wide Information Systems standardization as collective action: The case of U.S. residential mortgage industry. MIS Quarterly 30, 439-465 (2006)

12. Mylonopoulos, N.A., Theoharakis, V.: Global perceptions of IS journals - Where is the best IS research published? Communications of the ACM 44(9), 29-33 (2001)

13. Nelson, M.L., Shaw, M.J., Qualls, W.: Interorganizational System Standards Development in Vertical Industries. Electronic Markets 15(4), 378-392 (2005)

14. Orlikowski, W.J., Baroudi, J.J.: Studying information technology in organizations: Research approaches and assumptions. Information Systems Research 2(1), 1-28 (1991)

15. Petticrew, M., Roberts, H.: Systematic reviews in the social sciencesa practical guide. Blackwell, Malden (2006)

16. Rukanova, B.: Business transactions and standards: towards a system of concepts and a method for early problem identification in standa[r]d implementation projects. Enschede (2005)

17. Rumsey, S.: How to find information: a guide for researchers. Open University Press, Maidenhead (2008)

18. Schwartz, R.B., Russo, M.C.: How to quickly find articles in the top IS journals. Communications of the ACM 47(2), 98-101 (2004)

19. Söderström, E.: Formulating a general standards life cycle. In: Persson, A., Stirna, J. (eds.) CAiSE 2004. LNCS, vol. 3084, pp. 263-275. Springer, Heidelberg (2004)

20. Spivak, S.M., Brenner, F.C.: Standardization essentialsprinciples and practice. Dekker, New York (2001)

21. Steinfield, C.W., Wigand, R.T., Markus, M.L., Minton, G.: Promoting e-business through vertical IS standards: lessons from the US home mortgage industry. In: Greenstein, S., Stango, V. (eds.) Standards and Public Policy, pp. 160-207. Cambridge University Press, Cambridge (2007) 
22. Van der Linde, H., Hofstad, C.J., Geurts, A.C.H., Postema, K., Geertzen, J.H.B., van Limbeek, J.: A systematic literature review of the effect of different prosthetic components on human functioning with a lower-limb prosthesis. Journal of Rehabilitation Research and Development 41(4), 555-570 (2004)

23. Wareham, J.: Critical themes in electronic commerce researcha meta-analysis. JIT: Journal of Information Technology 20(1), 1 (2005)

24. Zhao, K., Xia, M., Shaw, M.J.: Vertical e-business standards and standards developing organizations: A conceptual framework. Electronic Markets 15(4), 289-300 (2005)

25. Zhu, K., Kraemer, K.L., Gurbaxani, V., Xin Xu, S.: Migration to Open-Standard Interorganizational Systems: Network Effects, Switching Costs, and Path Dependency. MIS Quarterly 30, 515-539 (2006) 